duszpasterskiich. Niektórzy duszpasterze starają się właśnie wtedy głosić słowo Boże wiernym przygotowującym się do spowiedzi. W ten sposób pragną oni podkreślić właściwe tło tego sakramentu, wykazać jak ujawnia się w nim owo pragnienie pokuty ożywiające Kościół.

c) Katechizacja, kazania, życie liturgiczne muszą wciąż uwydatniać znaczenie pokuty w życiu chrześcijańskim. Inaczej wysiłki o których mowa nie będą trwałe. Sakramentu pokuty nie można traktować w oderwaniu od całokształtu wysiłków duszpasterskich.

d) W powyższym ujęciu każdoroczny Wielki Post będzie zaiste okresem uprzywilejowanym jeżeli chodzi o głoszenie polkuty. Ukaże się nam bowiem ona w świetle tajemnicy paschalnej. Będzie jej przygotowaniem ale też i następstwem. ,Stary nasz człowiek został współukrzyżowany z Chrystusem, aby zniszczone była ciało grzechu. Tak i wy rozumiejcie, żeście umarli dla grzechu, a żyjecie dla Boga... Jak Chrystus powstał z martwych tak i my żyjmy wraz z Nim nowym życiem" (Rz 6, 5-11).

\title{
SACRA RITUUM CONGREGATIO INSTRUCTIO PRO SACERDOTE INFIRMO VEL CAECUTIENTE CIRCA MISSARUM VOTIVARUM CELEBRATIONEM EIDEM APOSTOLICO INDULTO CONCESSAM
}

$$
\text { I - PRAENOTANDA }
$$

1. Sacerdos infirmus vel caecutiens, seu visivae potentiae debilitate, sive accidentaliter sive habitualiter, laborans, a Sancta Sede dispensationem obtinere potest celebrandi, iuxta normas inferius expositas, aut aliquam Missam ex votivis, aut Missiam „quotidianam" defunctorum.

2. Conditiones huiusmodi privilegii ad amussim observandae sunt.

3. Si, durante privilegio, sacerdos caecutiens, plane caecus evadat, novum indultum a S. Congregatione de disciplina Sacramentorum obtinere debet; eoque obtento, sub gravi tenetur uti adsistentia alterius sacerdotibus vel diaconi.

\section{II - NORIMAE DE MISSIS VOTIVIS}

\section{A) Quae Missae votivae dici possint}

4. Sacerdos dispensatus dicere potest:

a) aut Missam Salve, sancta Parens, ut in Communi festorum B. Mariae Virg., quovis anni tempore;

b) aut Missam votivam de B. Maria Virg. pro diversitate temporum assignatam;

c) aut aliam Missam, quae tamquam votiva celebrari permittitur, iuxta nn. 306-316 Coldicis rubriciarum. 


\section{B) Quando Missa votiva dicenda sit}

5. Missa votiva dici potest quovis anni tempore; äici vero debet omnibus diebus, in quibus non permittuntur Missae defuntorum.

6. In Triduo sacro, sacerdos omnina a celebrando abstinebit.

7. In festo Nativitatis Domini, tres Missas dicere potest.

C) Quo colore utendum sit

8. Si sacerdos infirmus vel caecutiens privatim celébret semper colore albo uti potest.

Si vero in ecclesia aut oratorio publico vel semipublica celebret, adhibere potest colorem vel Missae votivae vel Officio diei conformem.

D) Quomodo Missa ordinada sit

9. Hymnus Gloria in excelsis Deo, dici potest semper nisi adhibeatur color violaceus paramentorum.

10. Regulariter dicitur unica oratio. Attamen fas est sacerdoti orationes addere, quae a rubricis praescribuntur vel permittuntur.

11. Symbolum dicitur:

a) quotiescumque dicendum est in Missa diei currentis;

b) si Misisa celebratur ad moidum Missae votivae I classis.

12. In quolibet Missa votiva dicitur praefatio communis, praeterquam in Missis de B. Maria Virgine, in quibus sumitur praefatio propria, adhibitis tamen semper verbis Et te in Veneratione.

13. Si Missa sit in cantu, tonus adhibetur solemnis vel ferialis, prout gradus diei currentis vel Missae votivae requirit.

\section{III - NORIMAE DE MISSIS DEFUNCTORUM}

14. Missa defunctorum dici potest diebus a rubricis permissis. Adhiberi tamen potest semper Missa "cotidiana", etiamsi Missa sit I, II vel III classis.

15. In Missa "quotidiana" unica semper dicitur oratio, nempe Fidelium. Eligi tamen potest et alia magis conveniens; et, si agitur de Missa lecta IV classis, addi potest et alia oratio ad libitum eligenda.

16. Missa "quotidiana“" adhiberi potest, et quidem ter si placuerit, in Commemoratione omnium Fidelium defunctorum.

17. Ad sequentiam Dies irae sacerdos numquam tenetur. Attamen si Missam I classis cantet, licet ipse sequentiam non legat, chorus eam cantare non omittat.

Summus autem Pontifex Ioannes Pp XXIII, in Audientia diei 12 aprilis 1961, hanc Instructionem in omnibus approbare dignatus est; atque sanxit ut ab omnibus, ad quos spectat, fideliter servetur.

Contrariis quibuscumquae non obstantibus.

Datum Romae, ex aedibus S. Rituum Congregationis, die 15 aprilis 1961.

$\uparrow$ C. Card. CICOGNANI, Pralefectus

H. Dante, a Secretis 


\section{KOMENTARZ}

Rytuał Rzymski zawiera Instrukcję S. K. O. o odprawianiu Mszy św. przez kapłana źle widzącego (pro sacerdote caecutiente), wydaną 12 stycznia 1921. Po ogłoszeniu przez Piusa XII dekretu o uproszczeniu rubryk, S. K. O. ogłosiła 15 grudnia 1957 poidobną Instrukcję obejmując nią nie tylko kapłanów tracących wzrok, lecz także chorych. Po ogłoszeniu Kodeksu rubryk powstala potrzeba zmiany Instrukcji dla kapłanów chorych i źle widzących.

1. Instrukcja odnosi się do kapłanów źle widzących oraz do kapłanów chorych, to jest takich, którzy dobrze widzą, ale ze względu na ogólny stan zdrowia nie mogą odprawiać MIszy zgodnej z oficjum dnia.

2. Wypada podkreślić, że kapłani, którzy już poprzednio otrzymali przywilej odprawiania Mszy wotywnej zachowują nadal ten przywilej na czas w indulcie określony. Winni jednak dostosować się do nowej Instrukcji.

3. Kapłan, który zupełnie utracił wzrok musi otrzymać nowy indult i jest zobowiązany korzystać $z$ asysty innego kapłana lub diakona. Dawniejsze instrukcje mówiły tylko o kapłanie. Były już wypadki udzielenia święceń kapłańskich niewidomym posługującym się alfabetem Braila. Ich Msze normują odrębne przepisy.

4. Dawniej kapłan korzystający $\mathrm{z}$ przywileju odprawiał albo zawsze piątą z wotyw a N. M. P., albo także inne wotywy o N. M. P. przepisane na okresy roku kościelnego. Obecnie kapłan może wybrać: albo Mszé wspólną na święta N. M. P., albo jedną z pięciu wotyw o N. M. P., albo jakąkolwiek inną wotywę. Możliwość szerszego wyboru jest cenna dla kapłanów chorych, lecz dobrze widzących. Mogą oni wybierać wotywy ściślej związane z okresem roku kościelnego i w ten sposób łączyć się z całym Kościołeem.

W święto Bożego Narodzenia kapłan korzystający z przywileju odczytuje w trzeciej Mszy ostatnią Ewangelię, jeżeli nie odprawiał trzeciej Mszy z dnia, która zawiera prolog św. Jana, jako Ewangelię mszalną.

8. Ponieważ wotywy $4 \mathrm{kl}$. można odprawiać w kolorze đnia, kapłan korzystający z przywileju może postąpić tak samo.

9. Nigdy $\mathrm{nie} \mathrm{ma} \mathrm{obowią} \mathrm{ku} \mathrm{odmawiania} \mathrm{hymnu} \mathrm{Gloria} \mathrm{in} \mathrm{excel-}$ sis Deo, natomiast można go zawsze odmówić, jeżeli nie odprawia się w szatach fioletowych.

10. Zasada regulująca odmawianie modlitwy jest podobnie elastyczna jak poprzednia. Zasadniczo odmawia się jedną modllitwę, lecz można dodać inne modlitwy przepisane (np. w rocznicę koronacji Papieża) lub dopuszczone ( $\mathrm{np}$. w rocznicę własnych święceń).

14. Jakko MIszę za zmarłych kapłan korzystający z przywileju może zawsze odprawiać Mszzę codzienną, ale może również użyć innych formularzy. Kapłan źle widzący może łatwo skorzystać z tej możliwości w czasie Mszy uroczystej, w której nie potrzebuje czytać Epistoły i Ewangelii. 
15. Przepisy o modlitwach we Mszy za zmarłych sa takie same jak dla innych kapłanów: w Mszach 1, 2 i 3 klasy jedna modlitwa, w Mszach 4 klasy można dodać inną.

Tyniec

O. FRANCISZEK MAEACZYNSSKI OSB

\section{DEKRET SWIĘTEJ KONGREGACJI OBRZĘDÓW}

Ponieważ w 1962 r. święto Najświętszego Serca Jezusowego zbiega się w dniu 29 czerwca ze świętem świętych Apostołów Piotra i Pawła, które według Kodeksu Rubryk n. 91, 3, ma pierwszeństwo, niektórzy Ordynariusze miejscowi prosili aby święto Najśw. Serca Pana Jezusa przenieść na inny dzień.

Dlatego też Święta Kongregacja Obrzędów, na polecenie Jego Świątobliwości Papieża Jana XXIII, postanawia, aby w tych krajach, w których święto świętych Apostołów Piotra i Pawła jest obowiązujące, święto Najśw. Serca Jezusowego obchodzono dnia 22 czerwca. w piątek po święcie Bożego Ciała.

Dla tych krajów należy zatem zmienić kalendarz następująco:

22 czerwca, piątek, Najśw. Serca Jezusowego,

$1 \mathrm{kl}$.,

28 czerwca, czwartek, Wigilia św. Ap. Piotra i Pawła $2 \mathrm{kl}$,

29 czerwca, piątek, św. Ap. Piotra i Pawła $1 \mathrm{kl}$,,

30 czerwca, sobota, Wspomnienie św. Pawła Ap., $3 \mathrm{kl}$.

Z Sekretariatu Sw. Kongregacji Obrzędów, dnia 13 grudnia 1961.

$\dagger$ C. Kard. CICOGNANI,

Bp Tuskulum, Prefek

Henryk Dante

Sekretarz

\section{WYJAŚNIENIA SWIĘTEJ KONGREGACJI OBRZĘDÓW}

I

WĄTPLIWOSCI, KTORE POWSTAEY PRZY INTEPRETOWANIU KODEKSU RUBRYK

Aby zadośćuczynić prośbom co do zewnętrznej uroczystości świąt, Swwięta Kongregacja, zasięgnąwszy zdania Komisji liturgicznej, postanowiła nadać takie brzmienie następującym numerom Kodeksu Rubryk:

N. $358-\mathrm{Z}$ samego prawa mają uroczystość zewnętrzną:

a) święto Najśw. Serca Jezusowego;

b)) święto Najśw. Maryi Panny Rǒżańcowej, w pierwszą niedzielę października; 